\title{
Densitas tulang alveolar pada penderita periodontitis kronis dan periodontitis agresif melalui radiografi
}

\author{
Rahmania', Lusi Epsilawati2 ${ }^{*}$, Nunung Rusminah ${ }^{3}$
}

\begin{abstract}
Objectives: The purpose of this study was to determine alveolar bone density in patients with chronic periodontitis and aggressive periodontitis through panoramic radiography.

Material and Methods: The method used in this study was descriptive. This study was conducted on populations that met all criteria. The sampling method used was purposive sampling technique, so that 31 panoramic radiographs were diagnosed with chronic periodontitis and 7 panoramic radiographs were diagnosed with aggressive periodontitis.

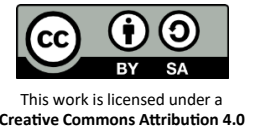

${ }^{1}$ Program Studi Pendidikan Dokter Gigi, Fakultas Kedokteran Gigi, Universitas Padjadjaran, Bandung, Indonesia, 40132

${ }^{2}$ Departemen Radiologi Kedokteran Gigi, Fakultas Kedokteran Gigi, Universitas Padjadjaran, Bandung, Indonesia, 40132

${ }^{3}$ Departemen Periodonsia, Fakultas Kedokteran Gigi, Universitas Padjadjaran, Bandung, Indonesia, 40132

\section{* Correspondence to:}

Lusi Epsilawati

凶lusifkg92@gmail.com

Received on: October 2019 Revised on: December 2019 Accepted on: January 2020
Results: The study showed that bone density in chronic periodontitis had an average of bony trabeculae $28.6 \%$ and marrow spaces $71.4 \%$ while bone density in aggressive periodontitis had an average bony trabeculae $20.2 \%$ and marrow spaces $79.8 \%$

Conclusion: Based on the results of the study it can be concluded that bone density in patients with chronic periodontitis and aggressive periodontitis has a low bone density value. The average bone density in patients with chronic periodontitis and aggressive periodontitis has different values, where the bone density in chronic periodontitis is greater than aggressive periodontitis.

Keywords: Chronic periodontitis, aggressive periodontitis, alveolar bone density, panoramic

Cite this article: Rahmania, Epsilawati L, Rusminah N. Densitas tulang alveolar pada penderita periodontitis kronis agresif melalui radiografi. Jurnal Radiologi Dentomaksilofasial Indonesia 2019;3(2)7-10. https:// doi.org/10.32793/jrdi.v3i2.484

\section{PENDAHULUAN}

Penyakit gigi dan mulut merupakan penyakit dengan urutan ke enam yang paling sering dikeluhkan oleh masyarakat Indonesia. ${ }^{1}$ Karies dan penyakit periodontal adalah dua penyakit gigi dan mulut yang mempunyai prevalensi tertinggi. Prevalensi penyakit periodontal mencapai 60\% pada masyarakat Indonesia. ${ }^{1}$ Fenomena di atas cukup menggambarkan masih tingginya risiko masyarakat Indonesia terkena penyakit periodontal. Penyakit periodontal merupakan suatu penyakit yang menyerang jaringan yang mengelilingi dan menyangga gigi, yang terdiri dari gingiva, sementum, ligamentum periodontal, dan tulang alveolar. ${ }^{2}$ Penyakit periodontal yang menyerang gingiva disebut gingivitis, apabila tidak dilakukan perawatan dapat berkembang menjadi periodontitis dimana terjadi kerusakan pada ligamen periodontal dan resorpsi pada tulang alveolar sehingga menimbulkan kegoyangan hingga terlepasnya gigi dari rahang. ${ }^{1}$ American Academy of Periodontology mengklasifikasikan penyakit periodontal dan kondisinya dalam dua bentuk, yaitu periodontitis kronis dan periodontitis agresif. ${ }^{3}$ Periodontitis kronis merupakan periodontitis yang umum terjadi pada usia dewasa dan berkembang lambat (slowly progressive periodontitis), sedangkan periodontitis agresif merupakan periodontitis yang bermula dini (early-onset periodontitis) dan berkembang cepat (rapidly progressive periodontitis). ${ }^{4}$

Updike et al. pada tahun 2008 mengatakan bahwa penderita dengan diagnosa periodontitis mengalami penurunan densitas tulang alveolar dilihat dari foto radiografi. ${ }^{5}$ Foto radiografi yang sering digunakan dokter gigi salah satunya adalah radiografi panoramik dimana dapat terlihat adanya pola destruksi tulang, pelebaran ligamen periodontal, radiodensitas, pola bony trabeculae, dan kontur marginal dari septum interdental. ${ }^{4,6}$ Taguchi et al. pada tahun 1996 dalam jurnalnya yang berjudul Pola bony trabeculae pada Mandibula menyatakan bahwa radiografi panoramik dapat memperlihatkan pola bony trabeculae dengan sangat baik. ${ }^{6}$ Jonasson et al. tahun 2001 menggunakan pola bony trabeculae sebagai indikator klinis untuk menentukan densitas tulang. ${ }^{7}$ Tujuan dari penelitian ini adalah untuk mengetahui densitas tulang alveolar pada penderita periodontitis kronis dan periodontitis agresif dengan menggunakan radiografi panoramik. 


\section{BAHAN DAN METODE}

Metode yang digunakan dalam penelitian in adalah metode deskriptif. Populasi adalah semua data radiografi panoramik pasien PPDGS (Program Pendidikan Dokter Gigi Spesialis) Periodonsia angkatan 2012-2013 di Rumah Sakit Gigi dan Mulut Universitas Padjadjaran Bandung (RSGM Unpad) dengan kasus periodontitis kronis sejumlah 61 pasien dan periodontitis agresif sejumlah 13 pasien, dimana radiograf panoramik terlihat dengan jelas terutama pada gigi M1. Kriteria ekslusi penelitian adalah semua data dari pasien memiliki komplikasi penyakit sistemik Diabetes Melitus, Down Syndrome, Chediak-Higashi Syndrome, PapillonLevevre Syndrome, Leukemia, Leukopenia, dan AIDS dan trauma oklusi. Sample yang digunakan pada penelitian ini adalah tulang alveolar bagian mesial dan distal gigi M1 yang diambil dengan teknik purposive sampling. Variabel yang akan di teliti pada penelitian ini adalah densitas tulang alveolar, dimana adalah perbandingan bony trabeculae dan marrow spaces yang menggambarkan kepadatan tulang disekitar gigi M1.

Teknik pengukuran yang dilakukan dengan menentukan ROI (Region of Interest) berupa kotak yang dibuat sebesar $3 \mathrm{~mm}^{2}$ dengan menggunakan software image J. ROI dibuat di bagian mesial dan distal tulang alveolar pada daerah defek paling apikal gigi M1 seperti pada Gambar 3, yang kemudian area tersebut dimasukkan ke dalam software Image J yang akan menghasilkan luas bony trabeculae dan marrow spaces dengan hasil berupa persentase.

\section{HASIL}

Pada hasil penelitian ini terlihat bahwa pasien periodontitis kronis pria dan wanita hampir sama, dengan jumlah pasien pria $16(51,6 \%)$ orang dan pasien wanita $15(48,4 \%)$ orang (Tabel 1). Tabel 2 memperlihatkan bahwa pasien periodontitis agresif pria dan wanita hampir sama dengan jumlah pasien pria $3(48,4 \%)$ orang dan pasien wanita lebih banyak yaitu $4(51,6 \%)$ orang. Tabel 3, menunjukkan pasien periodontitis kronis yang diteliti paling banyak berusia antara 36-45 tahun, sebanyak 11 (35,5\%) orang.

Tabel 4 memperlihatkan pasien periodontitis agresif yang diteliti paling banyak berusia antara 3645 tahun, sebanyak $4(57,1 \%)$ orang. Pada tabel 5 terlihat bahwa perbandingan bony trabeculae dan marrow spaces pada pasien periodontitis kronis terlihat signifikan dengan rata-rata bony trabeculae $28,6 \%$ dan marrow spaces $71,4 \%$. Pada tabel 6 terlihat perbandingan bony trabeculae dan marrow spaces pada pasien periodontitis agresif terlihat sangat signifikan dengan rata-rata bony trabeculae $20,2 \%$ dan marrow spaces $79,8 \%$.

Pada tabel 7 terlihat bahwa densitas tulang pada periodontitis kronis memiliki rata-rata bony trabeculae $28,6 \%$ dan marrow spaces $71,4 \%$ sedangkan densitas tulang pada periodontitis agresif memiliki rata-rata bony trabeculae 20,2\% dan marrow spaces $79,8 \%$, ini menunjukkan bahwa periodontitis kronis dan periodontitis agresif memiliki densitas tulang yang berbeda.

\section{DISKUSI}

Data yang diperoleh dari keseluruhan pasien PPDGS di Instalasi Periodonsia Kedokteran Gigi Rumah Sakit Gigi dan Mulut Universitas Padjadjaran Bandung yang didiagnosa periodontitis kronis dan periodontitis agresif menunjukkan perbedaan yang signifikan yaitu $4: 1$. Hal ini sesuai dengan penelitian sebelumnya bahwa penyakit periodontitis agresif timbul pada 1 dari 1000 remaja. ${ }^{8,9}$ Selain itu, penyakit periodontitis agresif memiliki predisposisi ras, lebih sering terjadi pada penduduk Afrika Barat. ${ }^{8,9,10}$ Hasil penelitian pada tabel 1 menunjukkan bahwa prevalensi penderita periodontitis kronis antara pria dan wanita hampir sama namun lebih besar pada pria. Hal ini sesuai
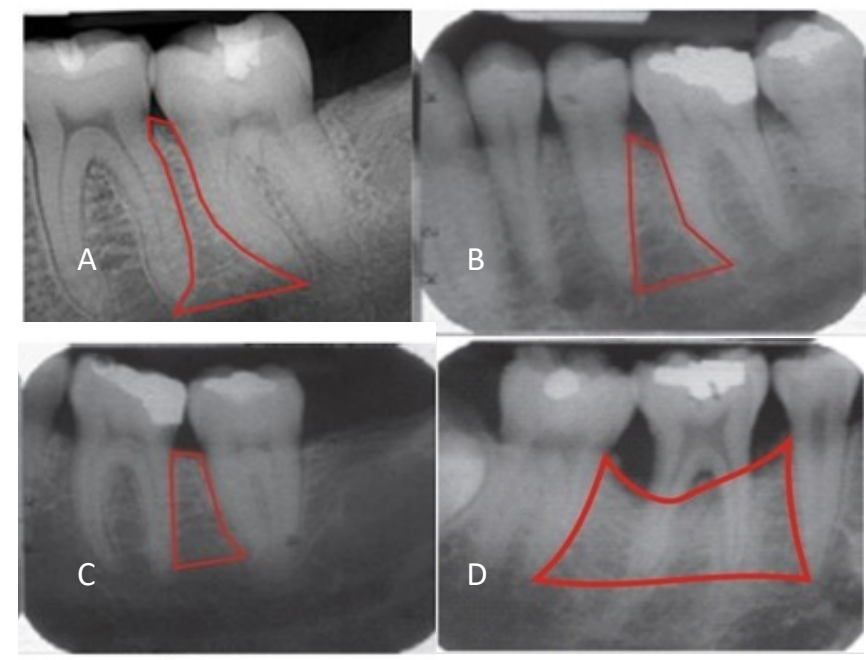

Gambar 1. Gambaran radiografi tulang alveolar pada kondisi: (A) normal; $(B, C)$ periodontitis kronis; (D) periodontitis agresif

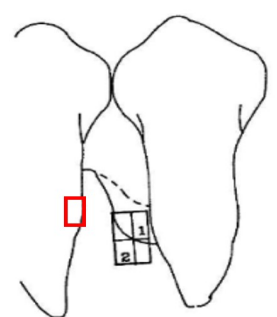

Gambar 2. Daerah defek paling apikal gigi ${ }^{5}$

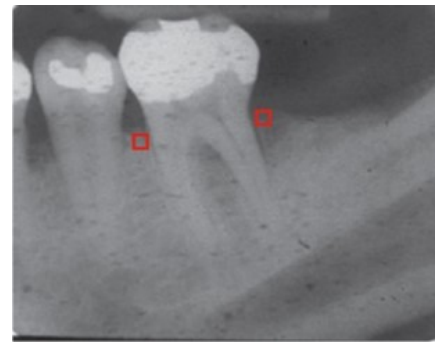

Gambar 3. Cara menentukan $\mathrm{ROI}^{5}$ 
dengan pernyataan bahwa prevalensi periodontitis kronis hampir sama antara pria dan wanita. Survei kondisi periodontal biasanya memperlihatkan bahwa pria dewasa memiliki risiko lebih tingg terserang periodontitis kronis dibanding wanita. Kebersihan mulut yang buruk adalah faktor terpenting yang memengaruhi prevalensi dan keparahan periodontitis kronis. Keparahan kerusakan pada semua kelompok usia terlihat lebih kecil pada wanita daripada pria, mungkin karena kebersihan mulut yang lebih baik pada wanita. ${ }^{8}$

Tabel 2 menunjukkan penderita periodontitis agresif pria dan wanita hampir sama, tetapi lebih banyak pada wanita. ${ }^{10,11,12} \mathrm{Hal}$ ini sesuai dengan pernyataan bahwa kondisi periodontitis agresif lebih sering terlihat pada wanita daripada pria dengan rasio $3: 1 .^{8}$ Albandar dalam jurnalnya mengenai Epidemiology and risk factors of periodontal disease juga menyatakan bahwa distribusi penyakit periodontitis agresif ditemukan lebih besar pada wanita. ${ }^{17}$
Hasil penelitian pada tabel 3, menunjukkan bahwa pasien periodontitis kronis dengan usia $>35$ tahun lebih banyak daripada pada usia $<35$ tahun. Hal ini sesuai dengan teori yang disampaikan bahwa penyakit periodontitis kronis biasanya diderita oleh pasien dengan usia 35 tahun ke atas. Hal ini sesuai dengan penelitian yang dilakukan peneliti pada tahun 2010 terhadap 262 pasien klinik periodonsia Jordan University of Science and Technolog, Dental Teaching Center bahwa persentase tertinggi pasien periodontitis kronis diderita oleh penderita berusia lebih dari 35 tahun. Prevalensi pada kelompok usia 19-25 tahun adalah $10-29 \%$ dan pada usia 45 tahun hampir $100 \%$ populasi sudah pernah mengalami kerusakan periodontal. ${ }^{14,15}$

Hasil penelitian pada tabel 4, menunjukkan bahwa penderita periodontitis agresif juga dapat menyerang penderita berusia di atas 30 tahun. $\mathrm{Hal}$ ini sesuai dengan pernyataan periodontitis agresif umumnya memengaruhi kondisi sistemik pasien sehat yang berusia kurang dari 30 tahun, meskipun

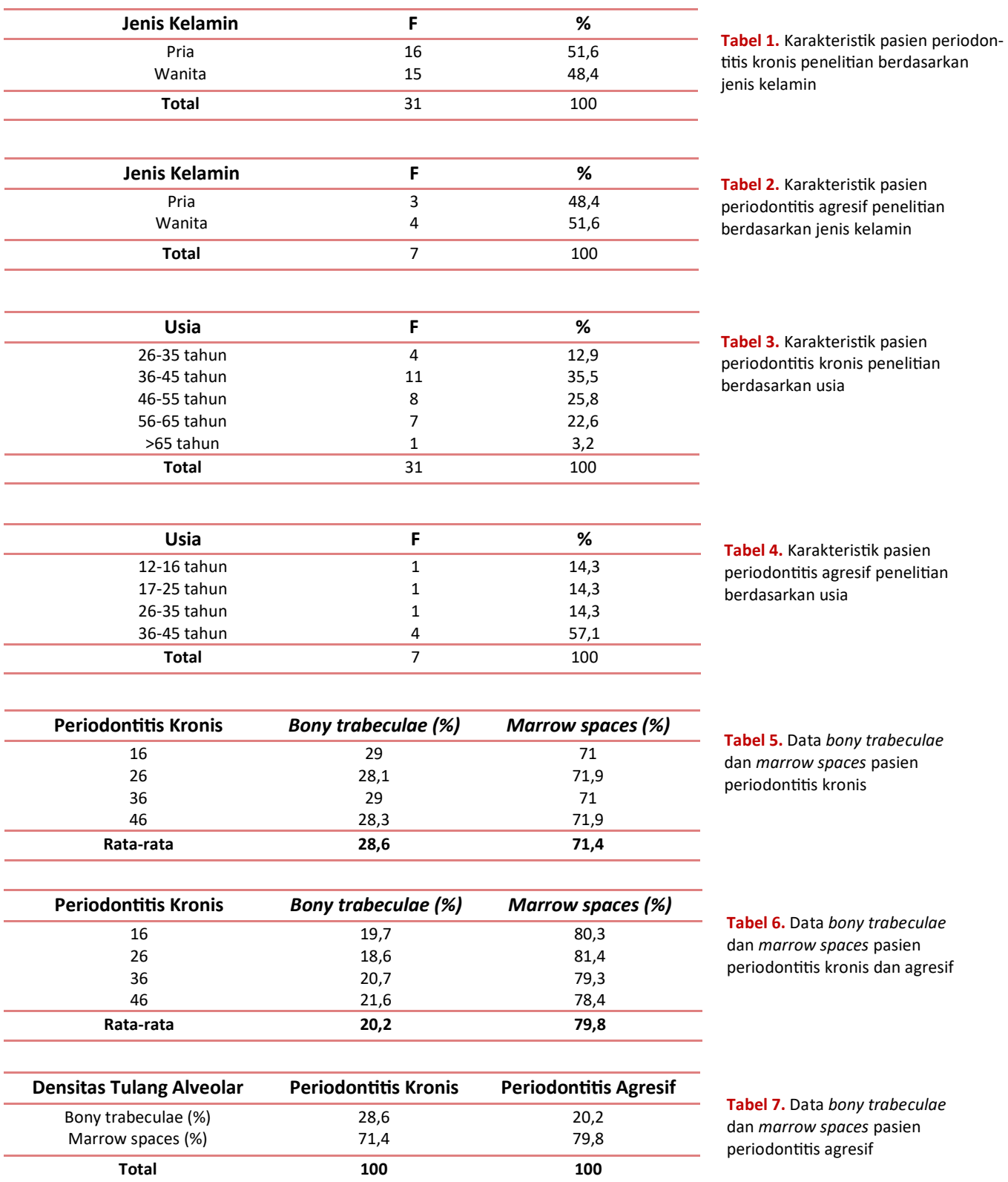


terkadang pasien mungkin lebih tua. ${ }^{17}$

Hasil penelitian pada tabel 5 dan 6 menunjukkan komposisi bony trabeculae pada tulang alveolar jauh lebih sedikit dibandingkan dengan komposisi marrow spacesnya. Densitas tulang sehat pada tulang alveolar dilihat melalui foto radiografi panoramik menunjukkan pola bony trabeculae dan marrow spaces yang seimbang. ${ }^{11}$ Hasil penelitian ini sesuai dengan pernyataan bahwa pasien yang menderita periodontitis mengalami penurunan densitas tulang alveolar. ${ }^{16}$

Pasien periodontitis kronis pada penelitian in memiliki rata-rata bony trabeculae yang rendah, yaitu 28,6\%. Pada patogenesis penyakit periodontitis kronis, terjadi penyebaran inflamasi dari gingiva ke puncak tulang alveolar ditandai dengan adanya infiltrasi sel-sel inflamasi ke ruangruang bony trabeculae. Prostaglandin yang terdapat pada gingiva yang terinflamasi dalam konsentrasi yang tinggi, merupakan perangsang yang poten untuk resorpsi tulang sehingga menyebabkan penurunan densitas tulang. ${ }^{11}$ Selain itu, beberapa mikroorganisme penyebab periodontitis kronis menghasilkan produk yang dapat memengaruhi resorpsi tulang, seperti Tannerella forsythia, Campylobacter rectus, Porphyromonas gingivalis dan spesies Treponema (T. Denticola). ${ }^{12}$

Pasien periodontitis agresif pada penelitian in memiliki rata-rata bony trabeculae yang rendah, yaitu $20,2 \%$. Patogenesis penyakit periodontitis agresif menyatakan bahwa pada penderita periodontitis agresif terdapat defek fungsional pada polymorphonuclearleukocytes (PMNs), monosit, atau keduanya. ${ }^{13}$ Defek ini dapat merusak, baik kemotaksis PMN terhadap daerah infeksi ataupun kemampuan fagositosis dan mengeliminasi mikroorganisme, khususnya Aggregatibacter actinomycetemcomitans. ${ }^{14}$ Bakteri gram negatif in menghasilkan leukotoksin yang kuat membunuh neutrofil, yang memberikan pertahanan penting terhadap infeksi periodontal dan rusaknya fungsi neutrofil. ${ }^{15,16}$ Dinding bakteri gram negatif mengandung lipopolisakarida (LPS, endotoksin) yang dikeluarkan setelah bakteri mati. LPS dapat menyebabkan nekrosis jaringan dan merangsang resorpsi tulang.

Hasil penelitian pada tabel 7, menunjukkan bahwa komposisi rata-rata bony trabeculae tulang alveolar pada periodontitis kronis dan periodontitis agresif berbeda. Periodontitis kronis menunjukkan komposisi rata-rata bony trabeculae tulang alveolar sebesar $28,6 \%$ sedangkan pada periodontitis agresif menunjukkan komposisi rata-rata bony trabeculae tulang alveolar sebesar $20,2 \%$. Hasil penelitian sebelumnya menyatakan aktivasi limfosit $T$ dan B lebih tinggi pada pasien periodontitis agresif daripada pasien periodontitis kronis. ${ }^{15,16}$ Limfosit B dan $T$ yang teraktifasi, menyebabkan aktivasi sistem imun melalui produksi faktor-faktor pengaktif osteoklas (OAF) yang dapat menyebabkan resorpsi tulang.

\section{SIMPULAN}

Berdasarkan hasil penelitian yang dilakukan dapat disimpulkan bahwa pasien dengan diagnosa periodontitis kronis maupun periodontitis agresif memiliki nilai densitas tulang yang rendah. Ratarata densitas tulang pada penderita periodontitis kronis dan periodontitis agresif mempunyai nilai yang berbeda.

\section{DAFTAR PUSTAKA}

1. Supriantoro, Oscar Primadi, tim Depkes. Porfil Kesehatan Indonesia. 2012. Kementrian Kesehatan RI.

2. Dorland, W.A.N. 2012. Kamus Saku Kedokteran Dorland. 28th ed. Singapore. Elsevier.

3. Artese, L., M. J. Simon, A. Piattelli, D. S. Ferrari, L. A. G. Cardoso, M. Faveri, T. Onuma, M. Piccirilli. 2011. Immunohistochemical Analysis of Inflammatory Infiltrate in Aggressive and Chronic Periodontitis: A Comparative Study. Clin Oral Invest 15(1): 233-240

4. Carranza, F. A., M. G. Newman, H. Takei, P. R. Klokkevold. 2015. Carranza's Clinical Periodontology. 12th ed. Philadelphia. W. B. Saunders

5. Updike, S. X., et al. 2008. Fractal Analysis of Dental Radiographs to Detect Periodontitis-Induced Trabecular Changes. J Periodont 10(1): 765-20.

6. Taguchi, A., K. Tanimoto, Y. Akagawa, Y. Suei, T. Wada, M. Rohlin. 1997. Trabecular Bone Pattern of The Mandible. Comparsion of Panoramic Radiography with Computed Tomography. Dentomaxilofac Radiology 26: 85-89.

7. Jonnason, G., G. Bankvall, S. Kiliaridis. 2001. Estimation of Skeletal Bone Mineral Density by Means of The Trabecular Pattern of The Alveolar Bone, Its Interdental Thickiness, and The Bone Mass of The Mandible. Oral Surg Oral Med Oral Pathol Oral Radiol Endod 92(3): 346-52.

8. Manson, J. D., B. M. Eley. 2012. Outline of Periodontics. 2nd ed. Jakarta. Hipokrates.

9. Ababneh, T. K., et al. 2010. The Association of Aggressive and Chronic Periodontitis with Systemic Manifestations and Dental Anomalies in A Jordanian Population: A Case Control Study. Head and Face Medicine 30(1): 6-30

10. Bolstad, A.I., H. B. Jensen, V. Bakken. 1996. Taxonomy, Biology, and Periodontal Aspects of Fusobacterium nucleatum. Clinical of Microbiology Reviews. pp. 55-71.

11. Kuramitsu, H. K., W. Chen, A. Ikegami. 2005. Biofilm Formation by the Periodontopathic Bacteria Treponema denticola and Porphyromonas gingivalis. J Periodontol 76(11): 2047-51.

12. Hunt, D.M. 2005. Bacteriology. Microbiology and Immunology On-line, Hunt, R.C. editor. http://pathmicro.med.sc.edu/ mhunt/flu.htm. University of South Carolina School of Medicine, Ch. 3, 4, and 10 .

13. Naito, M., H. Hirakawa, A. Yamashita, et al. 2008 Determination of the Genome Sequence of Porphyromonas gingivalis Strain ATCC 33277 and Genomic Comparison with Strain W83 Revealed Extensive Genome Rearrangements in P. gingivalis. DNA Res 15(4): 215-25.

14. Mishra, A. K., P. E. Fournier. 2012. The Role of Streptococcus intermedius in Brain Abscess. European Journal of Clinical Microbiology and Infectious Diseases. online.

15. Amit Mani, Rosiline James, Dr. Shubhangi Mani. Etiology and Pathogenesis of Aggressive Periodontitis: A Mini Review. Galore International Journal of Health Sciences and Research. 2018: 3(2) : 4-8

16. Omer Birkan Agrali1, Bahar Eren Kuru. Periodontal treatment in a generalized severe chronic periodontitis patient: A case report with 7] ? $y$ year follow? ?

17. Albandar JM. Epidemiology and risk factors of periodonta diseases. Dent Clin North Am. 2005;49(3):517-vi. doi:10.1016/ j.cden.2005.03.003 